\title{
Effect of Haemophilus influenzae Type b Lipopolysaccharide on Complement Activation and Polymorphonuclear Leukocyte Function
}

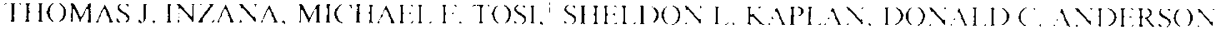 \\ HIDWARI)(). MASO) J.. ANI) R(OBIRT P. WIIIIAMS

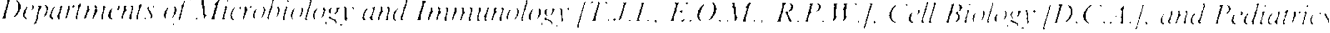

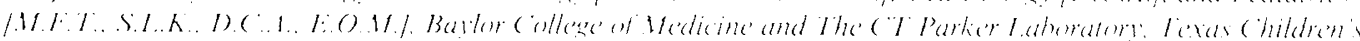

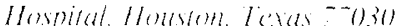

\begin{abstract}
ABSTRACI. Purified lipopolysaccharide (I.PS) from Haemophilus influenzae type b (I Iib) was examined for its capacity to interact with human hemolytic complement. generate conversion products of $(3,44$, and factor $B$ stimulate ( 5 a activity, and affect human neutrophil chemiluminescence and phagocytosis. Salmonella typhimurium I.PS and Salmonella minnesota Rb I.PS (R345 mutant) were examined for comparison. Incubation of Hib L.PS with human serum deficient in $\gamma$-globulin or with normal human serum containing $10 \mathrm{mVI} \mathrm{E(YT/4}$ and $7 \mathrm{m.M} \mathrm{MgCl}$ resulted in some depletion of hemolytic complement and conversion of ( 3 to degradation products (determined by inhibition of passive hemolysis and electrophoresis/immunofixation, respectively), indicating that complement activation occurred by the alternative pathway. (omplement activation by IIib I.PS and S. minnesota $\mathrm{Rb}$ I.PS was similar, but significantly less effective than by S. typhimurium I.PS $(p<0.01)$. Solubilized Hib lipid $A$, but not l.PS, induced conversion products of ( 4 in hypogammaglobulinemic serum, indicating activation of the classical pathway. Similar levels of (5a activity were generated by incubation of IIib I.PS and S. tryphimurium I.PS in hypogammaglobulinemic serum, as determined by neutrophil shape change and neutrophil aggregation. Ilib I.PS directly stimulated neutrophil chemiluminescence, whereas $S . t y$ phimurium I.PS had little effect. Phagocytosis of radiolabeled, opsonized I Iib by neutrophils was diminished by $S$. minnesota Rb L.PS, Irib I.PS, or solubilized Hib lipid I $(p<0.0(0)$ ). but was slightly increased by S. typhimurium I.PS. Neither the oligosaccharide of Ilib I.PS or Hib capsular polysaccharide was capable of interacting with complement or altering neutrophil chemiluminescence or phagocytosis. These results indicate that in comparison to S. typhimurium L.PS, Hib I.PS was less effective at activating complement, but more effective at impairing polymorphonuclear leukocyte function (Pediatr Res 22: 659$660,1987)$
\end{abstract}

Abbreviations

I.PS, lipopolysaccharide

Ilib, Haemophilus influenzae type b

Recoived March 31. 1987: accepted Iuly 26. $198 \%$

Reprint reguests Thomas J. Inzana, i)epartment of Pathoholugs Virginat Maryland Regional (allege of Veterinan Medicine. Virginia Tech. Blackshurg. VA $240(31$.

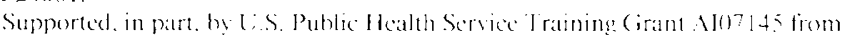
the National Institule of Alkergy and Infectious Discases

Present address (atse Western Reserve ( nuversity School of Medicine. 1)epant-

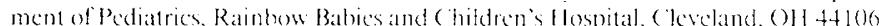

PMIN, polymorphonuclear leukocyte

I.ipid A-BSS1, the lipid moiety of I Hib I.PS complexed to bovine serum albumin

It $\gamma$ S, hypogammaglobulinemic serum

$\checkmark B S$, veronal buffered saline

vils, normal human serum

VISS-E.M, normal human serum containing $10 \mathrm{~m}$. I lagl and $7 \mathrm{mH}$ Mg( 1 ,

PBS, Inubecoos phosphate-buffered saline containing $0.2 \%$ 1)-glucose

IIBSS-gel. I Ianks" balanced salt solution containing $0.1 \%$ gelatin.

('PM, counts per minute

Hib is the ctiologic agent of a varieds of ststemic discases of children. including meningitis. epiglottitis, poncumonial and septicemia (1). As for other gram-negative bacteria. Hib has an outer membrane containing an endotoxic I PS. The lipid I compenent is similar in composition and biologic activity $l()$ the lipid $A$ of linterobacteriaceac (2), but the carbohvdrate movels is an oligosaccharide containing less 3-deoxy-i)-momme-2-octulosentic acid than enteric I.PS and no () side chains (i) (although Hib endotoxin is actually a lipooligosaccharide. the comventional momenclature I.PS wil! be used in this report) (t).

the repeating o side chains of entcric l.PS ate capalole of activating the alternative eomplement pathwas (5). Howerer. the structure of the carbohydrate. more so than the sise is critical for efficient activation of emplement (6-8). In the absence ot specific antibody. activation of complement by the allermative

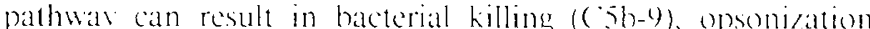

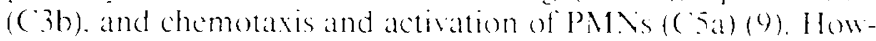
ever. the () side chains also promote backerial resistance to the kethal action of normal serum (10.11), 10 bactericidal proteins of PMV N (12), and inhibits opsonization and phasecontosis of the

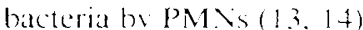

Hib I.PS lacks () side chains. however. the polvriboswlribitol phosphate capsule protects bacteria from the cidal acilion of normal serum and antisomatic antibodics and complement (1518). Depletion of complement in infant rats be cobral womom factor enhances bacteremia and meningitis by libo (19), indicating the importance of complement in host resistance lo llib infection. Intact thib is capable of activating the allernative complement pathwas $(20)$ and generating ( 5 al activits in normal serum (21). The component of Hib responsible for complement activation has not been idemified but does not appear to be the capsule (20). In addition. serum opsonization and phagencytosis

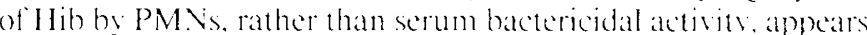


to be the most important complement-mediated factor in host defense against systemic infection $(22,23)$. The effect of Hib components on PMN function, however, has not been examined.

Herein we describe the capability of purified Hib LPS, Salmonella typhimurium LPS, and Salmonella minnesota Rb LPS to interact with complement, generate conversion product of $\mathrm{C} 3$. $\mathrm{C} 4$, and factor $\mathrm{B}$, induce $\mathrm{C} 5 \mathrm{a}$ activity in the absence of antibody. and to alter PMN chemiluminescence and phagocytosis. Our results indicate that in contrast to $S$. tiphimurium LPS, Hib LPS activates complement relatively poorly, and significantly reduces the capability of PMNs to phagocytize opsonized Hib.

\section{MATERIALS AND METHODS}

Bacteria and culture conditions. Hib strain Eag was kindly provided by Dr. Porter Anderson. University of Rochester Medical Center, Rochester, NY, and stored at $-70^{\circ} \mathrm{C}$ in sterile skim milk (15). A small aliquot was thawed and streaked on brain heart infusion agar supplemented with $2 \mathrm{mg} /$ liter factor $\mathrm{V}$ (nicotinamide adenine dinucleotide) and $5 \mathrm{mg} /$ liter factor $\mathrm{X}$ (hemin) (24). Several colonies were picked and grown in brain heart infusion broth supplemented with factors $\mathrm{X}$ and $\mathrm{V}$ at $37^{\circ} \mathrm{C}$ with shaking to mid log phase $\left(10^{9}\right.$ colony forming units $\left./ \mathrm{ml}\right)$. determined spectrophotometrically.

LPS and capsular polisaccharide. LPS from Hib strain Eag was isolated by enzyme digestion and phenol/water extraction (3). The chemical and physical properties of Hib Eag LPS have been previously described (3). Lipid-free oligosaccharide and lipid A was obtained by hydrolysis of a $1 \%$ solution of LPS in $1 \%$ acetic acid for $3 \mathrm{~h}$ at $100^{\circ} \mathrm{C}$. The carbohydrate moicty was purified by gel filtration on Sephadex G-50 (3) and the lipid was washed in distilled water, dried, and stored at $-70^{\circ} \mathrm{C}$. The lipid was solubilized with triethylamine and complexed to bovine serum albumin (lipid A-BSA) as described by Galanos et al. (25). LPS from $S$. typhimurium and from $S$. minnesota R345 (Rb LPS) was obtained from Sigma Chemical Co., St. Louis, MO, and List Biological Laboratories, Campbell. CA. respectively. Capsular polysaccharide from Hib was obtained from Lilly Research Laboratories, Indianapolis, IN.

Inhibition of hemolytic complement. Interaction of LPS with human complement was measured by inhibition of complementmediated lysis of opsonized sheep red blood cells as described (26), except that human $\mathrm{H} \gamma \mathrm{S}$ was used in place of guinea pig serum. The $\mathrm{H} \gamma \mathrm{S}$ was obtained from a patient with common variable immune deficiency: $\gamma$-globulin levels were $125 \mathrm{mg} / \mathrm{dl}$ for $\operatorname{IgG}, 12 \mathrm{mg} / \mathrm{dl}$ for $\operatorname{IgM}$, and $7 \mathrm{mg} / \mathrm{dl}$ for IgA. The $50 \%$ hemolytic complement activity of this serum was previously determined (27) and was normal. Various concentrations of LPS suspended in $20 \mu \mathrm{l}$ of distilled water were incubated in $100 \mu \mathrm{l}$ of $\mathrm{H} \gamma \mathrm{S}$ for $30 \mathrm{~min}$ at $37^{\circ} \mathrm{C}$. The samples were diluted to $300 \mu \mathrm{l}$, and $100 \mu \mathrm{l}$ were added to $1.5 \mathrm{ml}$ of $1.5 \%$ opsonized sheep red blood cells in VBS (M.A. Bioproducts, Walkersville, MD). The mixtures were incubated for $1 \mathrm{~h}$ at $37^{\circ} \mathrm{C}$ and centrifuged at 800 $\times g$ for $5 \mathrm{~min}$. The absorbance at $546 \mathrm{~nm}\left(\mathrm{~A}_{\$ 46}\right)$ was determined with a Gilford Rapid Sampler (Gilford. Oberlin. OH). The 100\% lysis control included distilled water in place of buffer and the $0 \%$ lysis control contained heat inactivated $\mathrm{H} \gamma \mathrm{S}\left(56^{\circ} \mathrm{C}\right.$ for 30 $\mathrm{min})$. The anticomplementary activity of various concentrations of LPS was expressed as the percent inhibition of hemolysis. Control samples containing no LPS caused $70 \%$ lysis of the erythrocytes. Inhibition of complement mediated lysis by a direct effect of LPS on the erythrocytes was examined by addition of LPS to red blood cell samples for $30 \mathrm{~min}$ at $37^{\circ} \mathrm{C}$ prior to addition of fresh complement. The $\mathrm{A}_{546}$ for all samples preincubated with LPS was within $10 \%$ of the serum control without LPS. Alternatively, activation of complement by the alternative pathway was measured using pooled NHS chelated with NHSEM and unopsonized rabbit erythrocytes as described by Riches and Stanworth (28).
Cleavage of complement proteins. Generation of conversion of products of $\mathrm{C} 3$. C4. and factor B was determined by electrophoresis of activated serum, followed by immunofixation of complement components. $\Lambda$ modification of the method described by Johnson (29) was used. One percent agarose (FMC Corporation, Marine Colloids Division, Rockland, ME) gels $(0.1-\mathrm{cm}$ thickness) in barbital buffer ( $\mathrm{pH} 8.6$ and ionic strength 0.075 ) containing $0.058 \%$ calcium lactate was solidified on $8 \times 9 \mathrm{~cm}$ "Gel Bond" mylar sheets (FMC Corporation. Rockland. ME). Concentrations ranging from 0 to $100 \mu \mathrm{g}$ of LPS in VBS were incubated in $1 \mathrm{ml}$ of NHS, NHS-EM, or $\mathrm{H} \gamma \mathrm{S}$ for $1 \mathrm{~h}$ at $37^{\circ} \mathrm{C}$. Activated serum was applied to a well in the sample mask on the paperblotted cathode side of the gel: for $\mathrm{C} 3$ and $\mathrm{C} 4,1 \mu \mathrm{l}$ of serum was applied to a $7 \times 0.5 \mathrm{~mm}$ well, and for factor B. $3 \mu \mathrm{l}$ was applied to a $10 \times 1 \mathrm{~mm}$ well. Serum was electrophoresed at $40 \mathrm{~mA}$ constant current for $1 \mathrm{~h}$. A $1: 1$ mixture of anti-C3 serum in Saline, neat anti-C4 serum (Atlantic Antibodies, Scarborough, $\mathrm{ME}$ ) or neat anti-factor B serum (donated by Dr. Gregory Buffone. Department of Clinical Chemistry. Texas Children's Hospital. Houston, TX) was then spread on the gel and covered with parafilm. The gel was incubated in a humid chamber for 1 $h$, pressed with a sheet of no. 40 Whatman filter paper and several sheets of no. 1 Whatman filter paper, and covered with a weighted glass plate for $10 \mathrm{~min}$. The gel was incubated in saline overnight with shaking. pressed with filter paper as described. thoroughly dried onto the mylar with a hair dryer, and stained with Coomassie Brilliant Blue R-250. The relative densities of the stained complement component bands were determined by densitometric scanning using a Quick-Scan Jr. thin-layer chromatographic densitometer and Quick-Quant III Computer set to the relative percent mode (Helena Laboratories, Beaumont. TX).

Generation of C 5 a activity in $\mathrm{H} \gamma \mathrm{S}$ by LPS diluted in VBS was measured by PMN shape change $(21,30)$ and by PMN aggregation $(31,32)$. These assays were used because they provide direct measurement of C5a activity (30-32) and because a functional analysis was desired concerning the interaction of Hib LPS with PMNs. A dose response curve plotting percent change in bipolar morphology of PMNs against the concentration of Hib LPS in NHS indicated that the percent of PMNs that underwent shape change increased in a linear fashion above background levels at LPS concentrations of $1 \mu \mathrm{g} / 0.2 \mathrm{ml}$ NHS $(49 \pm 2 \%)$ through 6 $\mu \mathrm{g} / 0.2 \mathrm{ml}$ NHS $(80 \pm 3 \%)$. Concentrations of more than $6 \mu \mathrm{g} /$ $0.2 \mathrm{ml}$ did not increase the percent of PMNs that underwent shape change. The same concentrations of S. typhimurium LPS gave results similar to those of Hib LPS. Therefore, additional experiments were performed with $5 \mu \mathrm{g}$ of LPS $/ 0.2 \mathrm{ml}$ of serum in order to remain below the plateau of the dose response curve.

Isolation of PMNS. Human PMNs from normal adults were separated from heparinized venous blood by sedimentation of erythrocytes in $0.6 \%$ dextran. The cells from the resulting leukocyte-rich plasma were centrifuged over a Ficoll-Hypaque solution, as previously described (21). The PMNs were incubated with LPS at this time, as described for each assay. After incubation with LPS, the remaining red blood cells were lysed with distilled water and the mixture containing the PMNs ( $>95$ by Wright stain) was isotonically restored with an equal volume of $1.8 \% \mathrm{NaCl}$. PMN suspensions were incubated with LPS in the presence of red blood cells to more closely simulate conditions in vivo. Control experiments in which the red blood cells were lysed prior to incubation with LPS indicated that red blood cells had no significant effect $(p<0.01)$ on LPS interaction with PMNs. The effect of LPS on PMNs was, however, slightly more pronounced in the absence of red blood cells (data not shown). Red blood cells were removed to avoid interference in the assays (e.g. quenching during chemiluminescence). Following removal of red blood cells the PMNs were sedimented at $800 \times g$ for 10 min and resuspended in Dulbecco's phosphate buffered saline (Gibco, Grand Island, NY), with 0.2\% D-glucose, pH 7.2 (PBS).

Chemiluminescence. Neutrophils ( $10^{6}$ in $300 \mu \mathrm{l}$ of PBS) were incubated with PBS alone or with 1,10 , or $100 \mu \mathrm{g}$ of LPS for 4 
hat $37^{\circ}$ C After incubation. the red blood cells were hypounically lysed, the PMNs restored to iscotonic conditions. and 1.5 $\mathrm{ml}$ of PBSS was added. One-hall ml of each suspension was then dispensed in triplicate to vials that contained $0.1 \mathrm{ml}$ of $10^{\circ} \mathrm{M}$ luminol (5-amino-2. 3-dihydroxy. 4-phthalizinedione: Sigma Chemical (o). St. Iouis. MO). Quantitation of chemiluminescence in these mixtures (linal volume. $1 .() \mathrm{ml}$ ) was performed in a liquid scintillation counter (model ( 2425 Tri-carb: Packard Instrument (ompany. Downers (irove. II.) in the out of coincidence mode. Values were obtained from the area under the curve in counts per 60 min with $1(0$-min intervals between counts (3.3). Data were expressed as the area under the curve for PMis incubated with IPS minus the area under the curve for PMNS incubated with PBS, divided by the area under the curve for PMNs incubated with PBS, times 100).

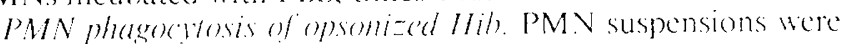
adjusted to 10$)^{\prime}$ cells/ml in RPMI-1640 medium (cibeo) and (0.4 $\mathrm{ml}$ of cells were incubated with PBSS or $40 \mu \mathrm{g}$ of I.PS in PBS for $16 \mathrm{~h}$ in closed $50 \times 9 \mathrm{~mm}$ Petri plates (Falcon. Oxnard. ( $\mathrm{A}$ ) at $37^{\circ}$ ( in a humidified chamber without shaking. as described by Hendricks of al. (34). After incubation with PBS or sample. distilled water was added to PMN suspensions to lyse red bleod cells and the PMNs were restored to isotonic condition with an equal volume of $1.8 \% \mathrm{NaC}$, The PMN were sedimented at 800$)$ $x g$ for $5 \mathrm{~min}$ and resuspended in the original volume with IIBSS-gel (cibco). Preliminary experiments were performed to assess the effect of incubation of I.PS on the viability of PMAis. On three separate occasions PMNs were incubated for $16 \mathrm{~h}$ with (), 10, or $100 \mu \mathrm{g}$ of I.PS exactly as described above. followed by trypan blue exclusion. Viability of control cells and cells incubated with 10 or $100 \mathrm{\mu g}$ of $1 . P S$ was $95 \% \pm 4 \%$. Phagocytosis of opsonized lib by incubated control cells was $10.5 \pm 0.7 \%$. Therefore, the capability of incubated PMVs to phagexytize opsonized llib in our assay was identical to that previously reported for fresh PMNs (27).

II. influenza' type b was grown overnight in BHI-XV containing 10 $\mu(\mathrm{C}$ "H-thymidine/ml (New England Vuclear. Boston. MA specific activity $77.2(\mathrm{i} / \mathrm{mmol})$ as previously described (27). The bacteria were adjusted to $10^{\prime \prime}$ colony forming units/ml. washed three times in PBS $(10.0(0) \times g$ for $10 \mathrm{~min})$. resuspended in PBS, and opsonized by incubation in pooled. heat-inactivated NIIS $(1: 1, v o l / \mathrm{vol})$ ior $45 \mathrm{~min}$ at $37^{\circ}$ (' with shaking. The opsonized bacteria were washed three times in PBS. resuspended in the original volume with IHBSS-gel, and held on ice until needed $(<1 h)$. The NHS used for phagocytosis of Hib had an antibody titer of $1: 512$ to Hib capsule determined by enzyme immunoassay (35).

Opsonized bacteria $(0.1 \mathrm{ml})$ were added to $0.25 \mathrm{ml}$ of PMNs at a final ratio of $80: 1$ in 1.5-ml microfuge tubes (Bel $\mathrm{Art}_{\mathrm{rt}}$ Products. Pequannock. VJ) and gently tumbled for $30 \mathrm{~min}$ at $37^{\circ}$ ( . The PMNs were washed three times in HBSS-gel at 150 $x y$ for 5 min and the inside of the tube was wiped dry following the last wash. Bacterial uptake was differentiated from adherence by incubation of control PMNs with bacteria at $0^{\circ}$ ('. Incubation of phagocytic cells with Salmonella at $4^{\circ}$ (' or less has been documented to inhibit phagocytosis (8). Experiments in our laboratory showed that incubation of onsonized Hib with PMNs for 20 min at $37^{\circ}$ ( resulted in about $11 \%$ association of bacteria with PMNs, whereas incubation at ()$^{\circ}$ ( resulted in less than $3 \%$ association after washing. The cells were resuspended in $0.35 \mathrm{ml}$ of PBS and added to $10 \mathrm{ml}$ of Scinti Verse 11 scintillation cocktail (Fisher. Houston. IX) and counted in a liquid scintillation counter. For each series of experiments, the percentage of uptake of ${ }^{3} \mathrm{H}$-Hib by neutrophils was determined from the ratio of ( $\mathrm{PM}$ of washed neutrophils exposed to opsonized bacteria to the (PM of the total number of opsonized hacteria exposed to neutrophils $\times 1(0)$. The $\left(\mathrm{PM}\right.$ of PMNs incubated with ${ }^{3} \mathrm{H}-\mathrm{H}$ ib at $0^{\circ}(\mathrm{C}$ was subtracted from the CPM of treated and untreated PM N incubated with ${ }^{3} \mathrm{H}$ - Itib at $37^{\circ} \mathrm{C}$.

Statistics. Significance was determined using the paired Stu- dent's t test on three or more separate experiments performed in triplicate (36).

\section{RFSIITS}

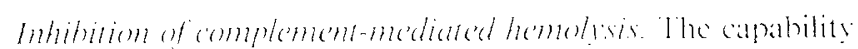

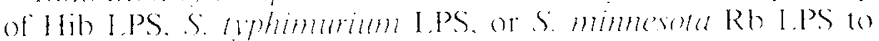
interact with complement in the absence of antibedy is shown in Figure 1. The concentration of S. Irphimmerum l. PS recuired to inhibit 50 " of the hemolytic activity of $\mathrm{H}_{7} \mathrm{~S}$ was $5 \mu \mathrm{g} / 0.1 \mathrm{ml}$. In contrast. neither Hih I.PS or S. minnesola Rb I.PS calused $50 \%$ inhibition of hemolysis at any concentration tested. At 45 $\mu \mathrm{g} / 0.1 \mathrm{~m}$ Hih I PS inhibited kess than $45 \%$ of the hemolytic activity of $\mathrm{H}, \mathrm{S}$. Concentrations of any I.PS of more than $45 \mu \mathrm{g} /$ 0. $1 \mathrm{ml}$ of serum did not increase inhibition of hemoly sis (data not shown). Hih I.PS was somewhat more active than Salmonella Rb I.PS but significantly less active than S. typhimurium I.PS at all concentrations tested $(p<0,01)$. In experiments not shown. similat differences in inhibition of hemolysis were secn when aach I.PS was incubated with VHS-I:M followed by incubation of the serum with rabbit erythrocytes. which are deficiont in sialie acid and activate the alternative complement pathway directly (28). Therefore, although S. Ayphimurium I.PS (containing () side chains) interacted with most of the available hemolytic complement. Hib I.PS (lacking 0 side chains) also hate some anticomplementary activity but only at relatively high 1.PS concentrations. Inhibition of complement-mediated hemolysis by I.PS in VHS-FM indicated that complement activation was bi the alternative pathwas:

Clearage of complement motein he l.P.S. Quantitative mealsurement of conversion products of $(3$. . (4. and factor 13 were made by electrophoresis of activated serum. followed by immumofixation and densitometry. The calpability of each I.PS to gencrate conversion products of $(3$ is shown in figure 2. 1)ensitometrie scanning of dried. stained gels provided cluantitative measurement of (3 conversion products by various carbohydrates or L.PHS in NHS. NHS-FM. or HoS (Table 1). The capsular polysaccharide of Hib and the lipid-free oligesaccharide

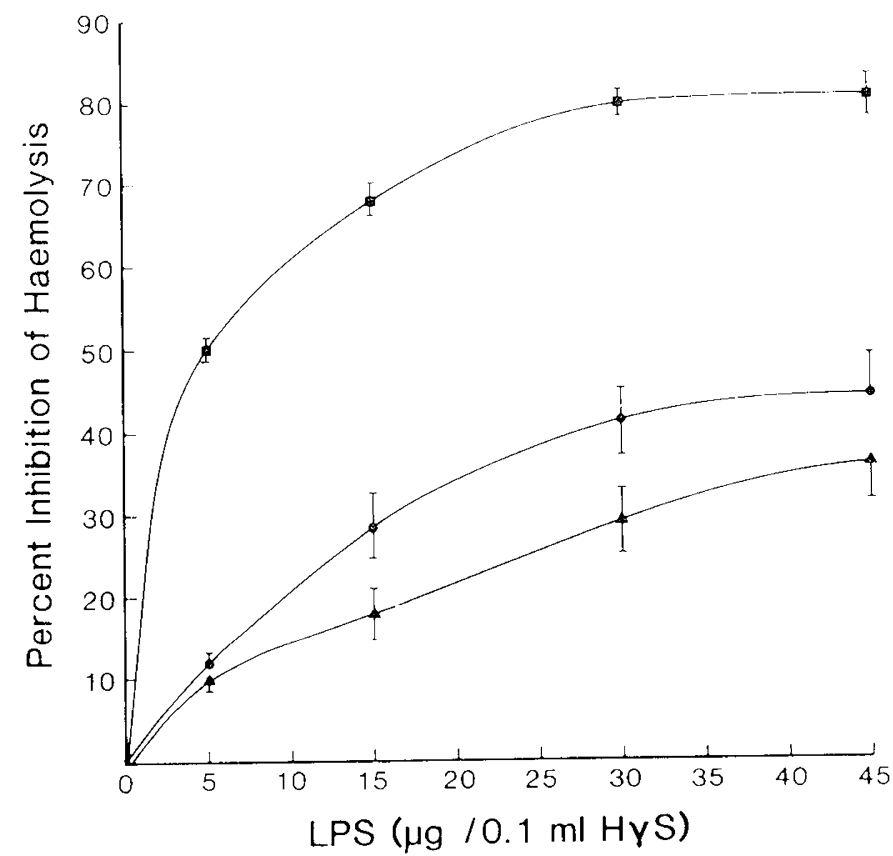

Fig. 1. Inhibition of hemolytic complement activity by I.PS. The I.PS $(5-45 \mu \mathrm{g}$ in $20 \mu$ of water) was incubated with $0.1 \mathrm{ml} 1 \mathrm{H}, \mathrm{S}$ for 30 min at $37^{\circ} \mathrm{C}$. The serum was diluted to $30(0) \mu \mathrm{l}$ with VBS and 100 , $\mu$ l was added to $1.5 \%$ sensitized sheep red blood cells in $1.5 \mathrm{ml}$ VBS. S.

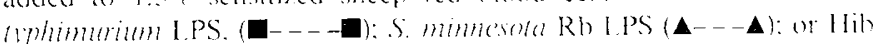

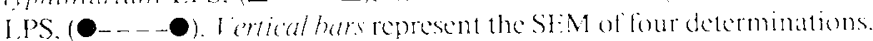




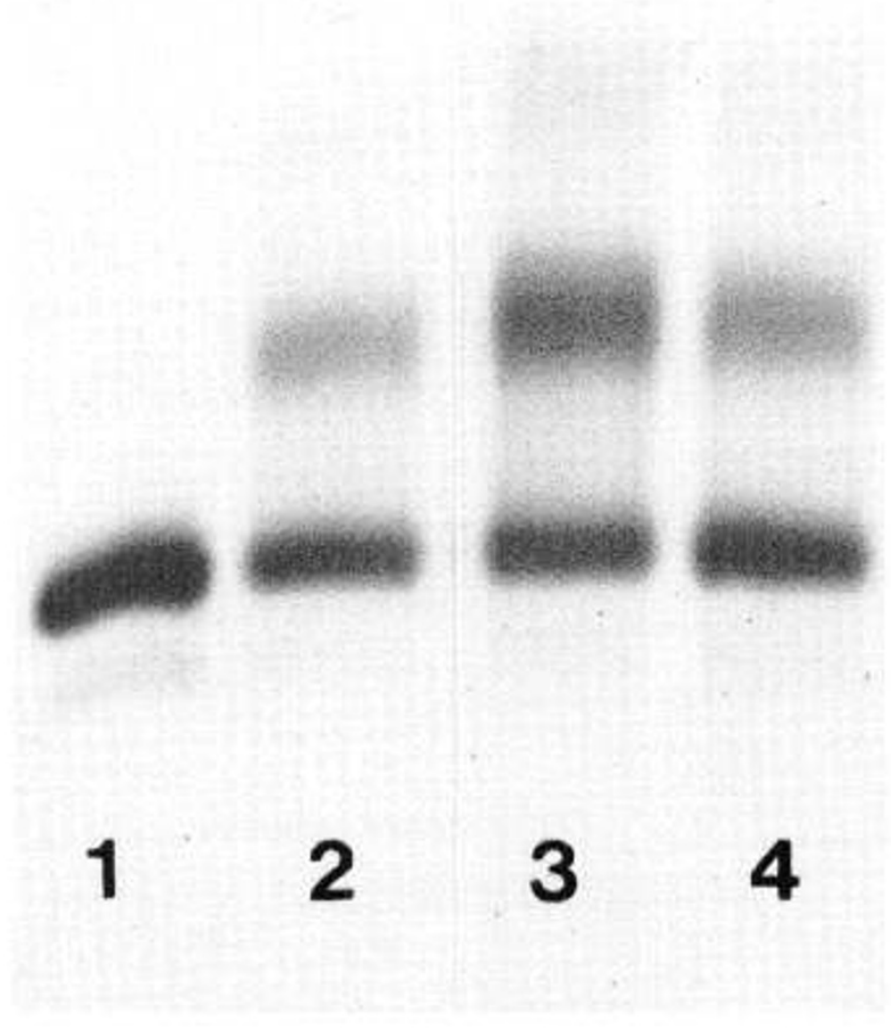

Fig. 2. Immunofixation of $\mathrm{C} 3$ conversion products following treatment of $\mathrm{H} \gamma \mathrm{S}$ serum with LPS. VBS or LPS was incubated in $\mathrm{H} \gamma \mathrm{S}$ for 1 $\mathrm{h}$ at $37^{\circ} \mathrm{C}$. The serum was then electrophoresed in $1 \%$ agarose and incubated with anti-C3 serum. The gel was washed, dried, and stained with Coomassie Brilliant Blue R250. Lanes and serum treatment: 1, VBS; 2, $100 \mu \mathrm{g} / \mathrm{ml}$ Hib LPS; 3, $100 \mu \mathrm{g} / \mathrm{ml}$ S. typhimurium LPS; 4, 100 $\mu \mathrm{g} / \mathrm{ml}$ Salmonella $\mathrm{Rb}$ LPS.

Table 1. Conversion of $C 3$ to degradation products in serum by LPS or carbohydrates

Percent conversion of $\mathrm{C} 3$ to degradation products*

\begin{tabular}{|c|c|c|c|}
\hline Sample & NHS & $\mathrm{NHS}+10 \mathrm{mM}$ EGTA-Mg $\mathrm{Mg}^{++}$ & $\mathrm{H} \gamma \mathrm{S}$ \\
\hline Veronal buffered saline & $<1$ & $<1$ & $<1$ \\
\hline $\begin{array}{l}\text { Capsular polysaccha- } \\
\text { ride }(100 \mu \mathrm{g} / \mathrm{ml})\end{array}$ & $<1$ & $<1$ & $<1$ \\
\hline $\begin{array}{l}\text { Hib (Eag) lipid-free oli- } \\
\text { gosaccharide }(100 \mu / \\
\text { ml) }\end{array}$ & $<1$ & $<1$ & $<1$ \\
\hline $\begin{array}{l}\mathrm{Hib}(\mathrm{Eag}) \text { LPS (100 } \\
\underset{\mu \mathrm{g} / \mathrm{ml})}{ }\end{array}$ & $41 \pm 2.9$ & $36 \pm 4.0$ & $38 \pm 1.5$ \\
\hline $\begin{array}{l}\text { S. minnesota Rb LPS } \\
(100 \mu \mathrm{g} / \mathrm{ml})\end{array}$ & $\mathrm{ND} \dagger$ & ND & $40 \pm 1.9$ \\
\hline $\begin{array}{l}\text { S. typhimurium LPS } \\
(100 \mu \mathrm{g} / \mathrm{ml})\end{array}$ & $66 \pm 1.4$ & $56 \pm 1.3$ & $55 \pm 1.5$ \\
\hline
\end{tabular}

* Percent conversion was determined by densitometry of dried, stained gels following electrophoresis and immunofixation.

$\dagger$ Not determined.

derived from Hib LPS did not cleave C3 in any serum used, whereas each intact LPS cleaved C3 in all sera tested. There was not a significant difference in the quantity of $\mathrm{C} 3$ conversion products formed in serum with only alternative pathway activity (NHS-EM) or in serum with classical and alternative pathway activity (NHS). However, significantly greater amounts of $\mathrm{C} 3$ conversion products were formed by $S$. typhimurium LPS compared with Hib LPS ( $p<0.01$ in NHS), whereas the amount of C3 conversion products generated by Hib LPS and S. minnesota $\mathrm{Rb}$ LPS was similar.

Lipid A from Hib Eag solubilized with bovine serum albumin cleaved most of the $\mathrm{C} 4$ present in $\mathrm{H} \gamma \mathrm{S}$ (Table 2), indicating $\mathrm{Hib}$ lipid A activated the classical pathway, as does enteric lipid A (5, 25). Each intact LPS failed to generate any detectable level of $\mathrm{C} 4$ conversion products, but did generate conversion products of factor B, a component of only the alternative pathway (Table 2). Therefore, the carbohydrate moieties of both rough and smooth LPSs apparently blocked activation of the classical pathway by lipid A.

Generation of C5a activity was assayed by alteration of PMN bipolar morphology or aggregation after incubation of $\mathrm{H} \gamma \mathrm{S}$ with Hib LPS or S. typhimurium LPS. Preliminary experiments demonstrated that when the concentration of Hib LPS was increased from 0.1 to $6 \mu \mathrm{g} / 0.2 \mathrm{ml}$, the percent of PMNs undergoing bipolar shape change increased linearly in a manner similar to that seen with increasing C5a concentration (30). This effect was not due to a direct effect of LPS on the PMNs because the percent change in bipolar morphology of control PMNs incubated with LPS and heat-inactivated serum $\left(56^{\circ} \mathrm{C}\right.$ for $\left.30 \mathrm{~min}\right)$ remained constant; percent shape change in these controls was similar to control PMNs incubated with fresh serum without LPS. Serum incubated with either Hib LPS or S. typhimurium LPS induced a similar increase in the percentage of PMNs that underwent shape change (Fig. 3). Incubation of fresh $\mathrm{H} \gamma \mathrm{S}$ with anti-C5 serum, after incubation with either S. typhimurium LPS or Hib LPS, reduced activity nearly to that of $\mathrm{H} \gamma \mathrm{S}$ incubated with buffer only, indicating the change in PMN morphology was most likely associated with generation of $\mathrm{C} 5 \mathrm{a}$. In experiments not shown herein, $\mathrm{H} \gamma \mathrm{S}$ incubated with Hib LPS or S. typhimurium LPS could also induce PMN aggregation, another method for determination of $\mathrm{C} 5$ a activity $(31,32)$. As for alteration in bipolar morphology, serum incubated with Hib LPS or S. typhimurium LPS did not differ in capacity to induce PMN aggregation.

Effect of LPS on PMN chemiluminescence. In preliminary experiments, $10^{6}$ PMNs were incubated with 1,10 , or $100 \mu \mathrm{g}$ of Hib LPS or $S$. typhimurium LPS for 1, 4, or $16 \mathrm{~h}$, followed by measurement of the chemiluminescence response in the presence of luminol. The optimal incubation time was 4 or $16 \mathrm{~h}$, although a response occurred after at least $1 \mathrm{~h} ; 4 \mathrm{~h}$ was used for additional experiments. One or $10 \mu \mathrm{g}$ of either Hib LPS or S. typhimurium LPS had no significant effect on PMN chemiluminescence $(p>$ 0.05 ), whereas $100 \mu \mathrm{g}$ of Hib LPS-but not S. typhimurium LPS-significantly increased chemiluminescence compared with control PMNs incubated with PBS $(p<0.001)$ (Table 3). Therefore, Hib LPS was capable of directly stimulating a PMN metabolic burst, whereas $S$. typhimurium LPS did not.

Effect of LPS on PMN phagocytosis. Neutrophils $\left(10^{7} / \mathrm{ml}\right)$ were pretreated with Hib LPS $(100 \mu \mathrm{g} / \mathrm{ml})$ or buffer (RPMI- 1640 medium) and incubated with opsonized, ${ }^{3} \mathrm{H}$-labeled $\mathrm{Hib}$ at 37 or $0^{\circ} \mathrm{C}$ for 5,10 , or $20 \mathrm{~min}$; CPM of PMNs incubated with ${ }^{3} \mathrm{H}-\mathrm{Hib}$ at $0^{\circ} \mathrm{C}$ was subtracted from CPM of treated or untreated PMNs incubated with $\mathrm{Hib}$ at $37^{\circ} \mathrm{C}$ to differentiate adherence from uptake. Phagocytosis of opsonized Hib by PMNs pretreated with buffer was $10-11 \%$, which is identical to the extent of uptake previously reported for this bacterium at this bacterium:PMN ratio (27). There was a significant $(p<0.001)$ decrease in the rate of phagocytosis of opsonized Hib by PMNs pretreated with Hib LPS in comparison to controls incubated with buffer, and the decrease was linear with respect to time of incubation (Fig. 4). Therefore, incubation of human PMNs with Hib LPS was detrimental to PMN phagocytic activity for opsonized Hib.

Comparative analysis of each compound's effect on PMN phagocytosis is shown in Figure 5. In comparison with buffer, Hib LPS significantly decreased PMN phagocytosis of opsonized Hib $(p<0.001)$, whereas $S$. typhimurium LPS moderately increased phagocytosis $(p>0.05)$. S. minnesota Rb LPS and the 
Table 2. Cleavage of ( 4 and factor B by LPS or IIib lipid 1 in $\mathrm{H \gamma} S$

Sample

Veronal buffered saline

Hib (Eag) LPS + LPS antibody

Hib (Eag) Lipid $\wedge$-BSA $(100 \mu \mathrm{g} / \mathrm{ml})$

Hip (Eag) I.PS $(100 \mu \mathrm{g} / \mathrm{ml})$

S. minnesota R345 LPS $(100 \mu \mathrm{g} / \mathrm{ml})$

S. typhimurium LPS $(100 \mu \mathrm{g} / \mathrm{ml})$
$\%$ conversion of

C4 to degradation products*

$$
<1
$$

$27 \pm 1.7$

$83 \pm 1.5$

$<1$

$<1$

$<1$
$\%$ conversion of

factor B to degradation products*

$$
\begin{gathered}
<1 \\
\text { ND }+ \\
\text { ND } \\
15 \pm 1.2 \\
12 \pm 2.1 \\
33 \pm 1.5
\end{gathered}
$$

* Percent conversion was determined by densitometry of dried. stained gels following electrophoresis and immunofixation.

$\uparrow$ Not determined.

Free lipid $A$ was solubilized with $1 \mu \mathrm{l}$ of triethylamine $/ \mathrm{ml}$ of lipid $\mathrm{A}(2 \mu \mathrm{g} / \mathrm{ml})$, mixed with $2 \mu \mathrm{g} / \mathrm{ml}$ of BSA. and the lipid $A$-BSA were complexed by lyophilization.

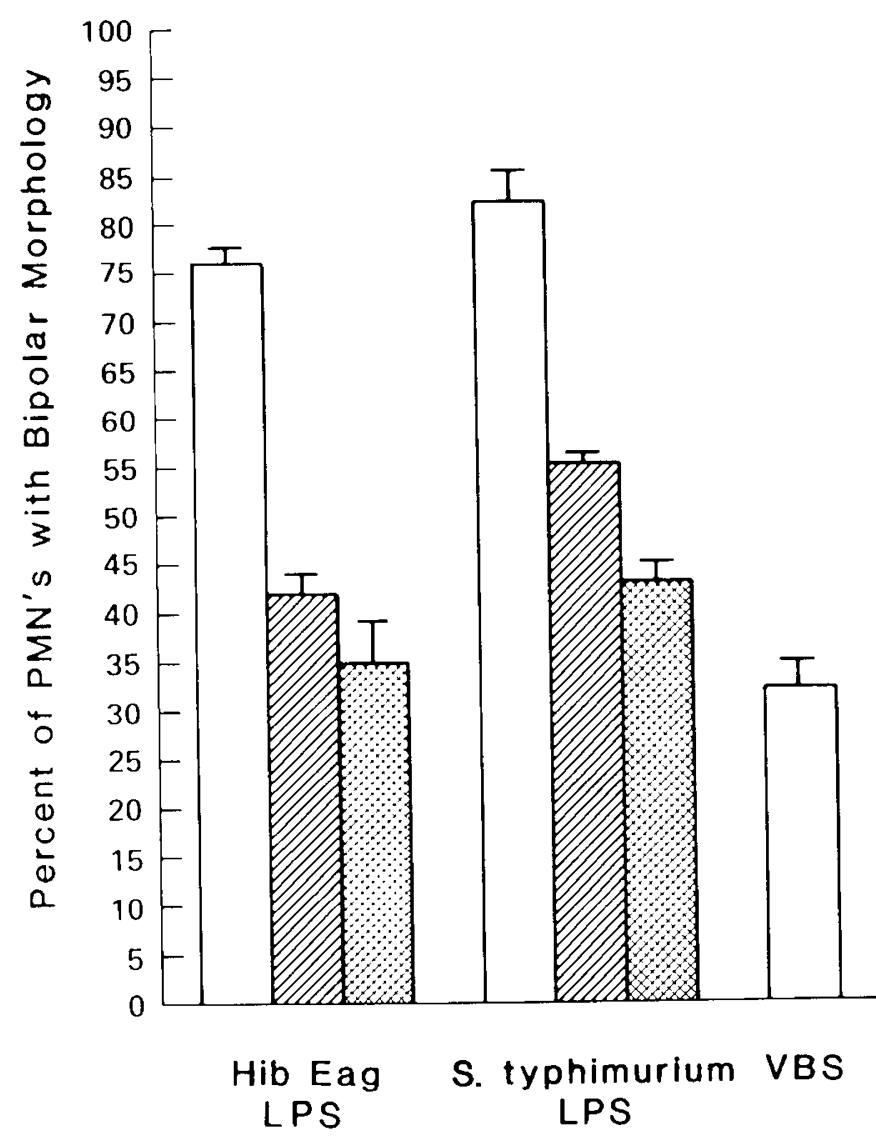

Fig. 3. Change in bipolar morphology of PMNs following incubation of $\mathrm{H} \gamma \mathrm{S}$ with LPS. Purificd L.PS from Hib Eag or S. typhimurium $(5 \mu \mathrm{g})$ was incubated with untreated (no lines) or heat-inactivated (single slashed lines) $\mathrm{H} \gamma \mathrm{S}$ for $1 \mathrm{~h}$ at $37^{\circ} \mathrm{C}$ before incubation of serum with PMNs. Anti-C5 serum was incubated with fresh $\mathrm{H} \gamma \mathrm{S}$ (cross-hatch lines). at $37^{\circ} \mathrm{C}$ for $30 \mathrm{~min}$ immediatcly following incubation with LPS. VBS was used as diluent and to control for nonspecific activity of $\mathrm{H} \gamma \mathrm{S}$. Vertical hars represent the SEM of three determinations.

solubilized lipid moiety of Hib LPS also decreased phagocytosis to a level similar to that induced by Hib LPS. Preincubation of PMNs with Hib lipid-free oligosaccharide or capsular polysaccharide prior to incubation with opsonized, ${ }^{3} \mathrm{H}$-Hib, however. did not enhance or diminish PMN phagocytosis (data not shown). Therefore, the lipid moiety of Hib LPS had a detrimental effect on PMN phagocytosis, and its activity was not substantially blocked by the oligosaccharide moiety. Similarly, the oligosaccharide of Salmonella Rb LPS did not influence the effect of lipid A on PMN phagocytosis, whereas the high molecular weight polysaccharide of S. typhimurium LPS did appear to exert a moderating effect.
Table 3. PMN chemiluminescence in response to Hib L.PS or S.

$$
\begin{aligned}
& \text { typhimurium LPS* } \\
& \text { Concentration }\left(\mu \mathrm{g} / 10^{6}\right. \\
& \text { PMNS) } \\
& \text { LPS } \\
& 10 \% \text { increase in } 100 \\
& \text { chemiluminescence } \\
& \text { II. influenzae b (Eag) } \\
& 18 \pm 10.4 \quad 68 \pm 10.6 \\
& \text { S. typhimurium } \\
& 27 \pm 10.5 \\
& 1.3 \pm 11.5
\end{aligned}
$$

* LPS $\left(10\right.$ or $100 \mu \mathrm{g}$ in PBS) or PBS only was incubated with $10^{6}$ PMNs for $4 \mathrm{~h}$ at $37^{\circ} \mathrm{C}$. The red blood cells were lysed in distilled water to avoid quenching. and the PMNs isotonically restored and diluted in PBS. Luminol was added and the total counts per 60 min determined. Values are expressed as the percent increase in chemiluminescence by PMNs incubated with LPS relative to PMNs incubated with PBS.

+ Values represent the mean of at least three experiments performed in triplicate \pm SEM.

\section{DISCUSSION}

Functional complement activity is essential for host resistance to Hib infections (19). Hib has been reported capable of activating the alternative complement pathway (20). However, anticapsular antibody is required for bactericidal activity in normal serum $(37,38)$ : antisomatic antibodies to Hib do not activate complement-mediated bactericidal activity by the alternative pathway (37). There is evidence that the most critical complement-mediated event in host resistance to Hib infection is opsonization and phagocytosis by PMNs, rather than bactericidal antibody $(22,23)$. Therefore, study of the interaction of purified Hib components with complement may aid in understanding the pathogenesis of Hib disease. Hib LPS is a biologically active endotoxin (2). however, the interaction of purified Hib LPS with host defense systems has not previously been reported. We examined the capability of Hib LPS to interact with human PMNs in comparison to S. typhimurium LPS and Salmonella Rb LPS. Since the physical and chemical propertics of LPS may influence their biologic activity. Hib Eag LPS was used because it has been characterized more extensively than any other Hib LPS $(2,3)$. Furthermore. Rb LPS from Salmonella R345 was used for comparison because the molecular weight and solubility of the Rb LPS was similar to that of Hib Eag LPS (3) (Inzana T, unpublished data), and because the interaction of rough and smooth Salmonella LPS for complement and PMNs has been characterized $(5,26,39-41)$.

Activation of the alternative complement pathway has been shown to be a function of the 0 side chain repeating units of LPS (5). Therefore as expected, S. typhimurium LPS was highly active in interacting with complement. The concentration of $S .1 \mathrm{p} / \mathrm{hi}$ murium LPS required for $50 \%$ inhibition of complement-mediated hemolysis in our study was similar to that reported by Galanos and coworkers $(26,39)$. Salmonella Rb LPS has previ- 


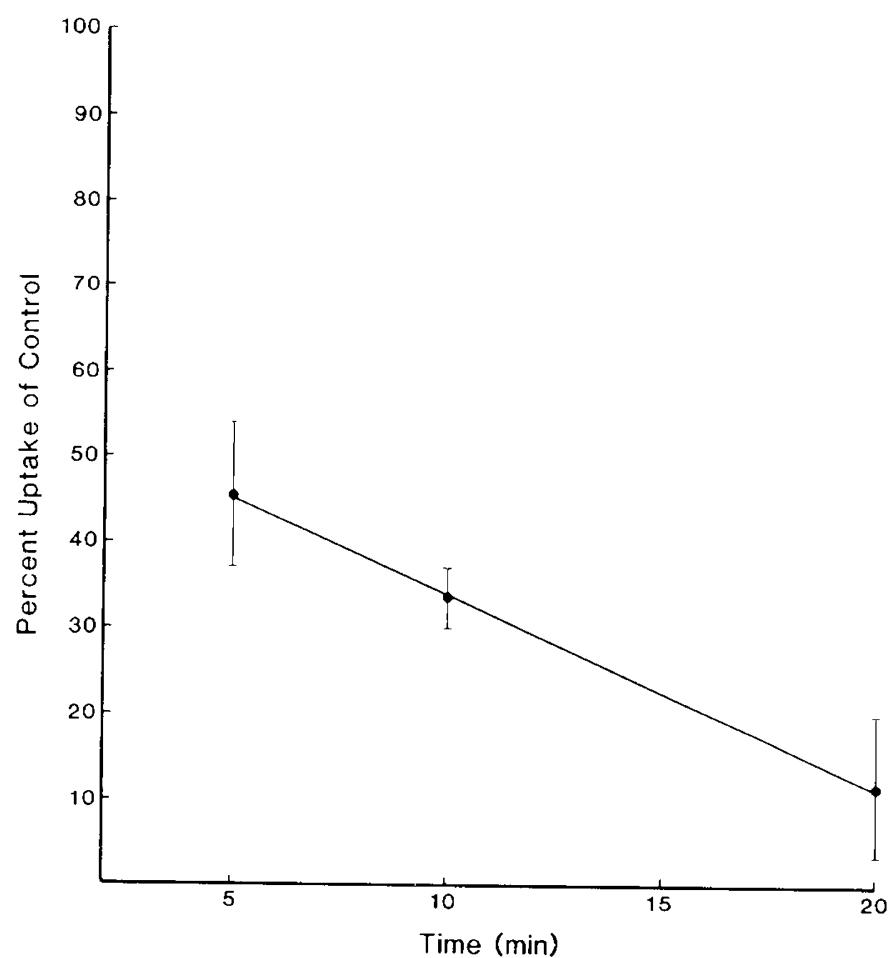

Fig. 4. Effect of Hib LPS on kinetics of PMN phagocytosis of opsonized Hib. LPS $(40 \mu \mathrm{g})$ or PBS was incubated with $4 \times 10^{6}$ PMNs for 16 $\mathrm{h}$ at $37^{\circ} \mathrm{C}$ in $5 \% \mathrm{CO}_{2}$. The red blood cells were lysed and the washed PMNs were incubated with opsonized, radiolabeled Hib (1:80) at 37 or $0^{\circ} \mathrm{C}$ for 5,10 , or $20 \mathrm{~min}$. The PMNs were washed three times and the percent uptake of radiolabeled bacteria by PMNs was determined by liquid scintillation counting relative to total bacterial counts. The CPM of PMNs incubated with ${ }^{3} \mathrm{H}-\mathrm{Hib}$ at $0^{\circ} \mathrm{C}$ was subtracted from the CPM of PMNs incubated with ${ }^{3} \mathrm{H}$-Hib at $37^{\circ} \mathrm{C}$, and the percent uptake of $\mathrm{Hib}$ was determined. Values are expressed as the percent uptake of ${ }^{3} \mathrm{H}-\mathrm{Hib}$ by PMNs treated with LPS relative to control PMNs incubated with PBS. The vertical bars represent the SEM of three determinations.

ously been shown to be a poor activator of the complement system $(26,39)$, which was confirmed by our results. Hib LPS was capable of initiating activation of the alternative complement pathway, but only at relatively high concentrations. In addition to consumption of hemolytic complement, each LPS generated conversion products of $\mathrm{C} 3$ and factor $\mathrm{B}$ in sera with only alternative complement pathway activity. As for inhibition of complement consumption, however, immunofixation indicated that S. typhimurium LPS was significantly more active than Hib LPS or Salmonella Rb LPS. Although immunofixation cannot be used to quantitate generation of $\mathrm{C} 3 \mathrm{~b}$, the technique is highly efficient and easily interpreted. When combined with scanning densitometry, immunofixation provides accurate quantitative measurement of complement activation and conversion to degradation products (42). However, C3d and other low molecular weight conversion products may not be detected by the assay. Failure of bacteria to efficiently activate complement results in poor opsonophagocytosis and may thereby enhance virulence (43). In addition, although 0 side chains activate complement they also provide the bacterium protection against the bactericidal activity of serum $(10,11)$. Hib LPS lacks 0 side chains (3), however, the capsule provides protection to $\mathrm{Hib}$ against the bactericidal activity of antisomatic antibodies and complement (16-18). Therefore, the combination of a protective capsule and an LPS that is a poor activator of complement may act together to enhance bacterial resistance to host defense mechanisms.

Hib lipid A was shown to be capable of activating the classical

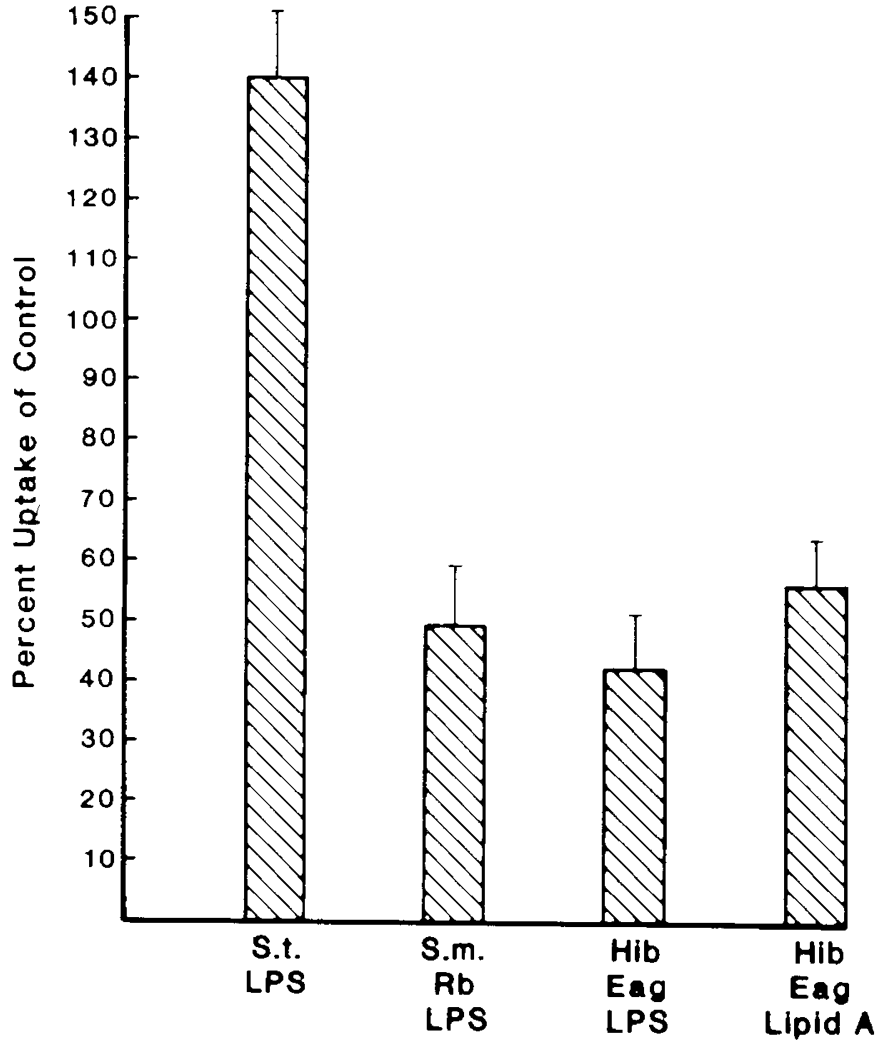

Fig. 5. Effect of LPS or Hib lipid A on PMN phagocytosis. PMNs were pretreated with each LPS or solubilized lipid A $(40 \mu \mathrm{g})$, or PBS, as described in Figure 4, and incubated with radiolabeled, opsonized Hib for 20 min at 37 or at $0^{\circ} \mathrm{C}$. The PMNs were washed and assayed as described in Figure 4. Vertical bars represent the SEM of four determinations.

complement pathway, but only after the carbohydrate moiety was removed and the lipid complexed to bovine serum albumin. These results are identical to those reported by Galanos et al. (25) for enteric lipid A. Studies have shown that even a relatively small amount of carbohydrate can block the activation of $C 1$ by lipid A (44). Therefore, it would be unlikely that activation of the classical complement pathway by Hib lipid A would occur in vivo.

Intact $\mathrm{Hib}$ has previously been shown to be capable of generating $\mathrm{C} 5 \mathrm{a}$ in serum, but the somatic components responsible were not identified (21). C5a is chemotactic for PMNs and activates them, resulting in aggregation and changes in their bipolar morphology (30-32). These assays were selected because they directly measure the functional activity of C5a, which was more relevant to these studies than immunochemical quantitation. Inhibition of change in bipolar morphology with anti-C5 serum or heated $\mathrm{H} \gamma \mathrm{S}$ further indicated that changes in bipolar morphology were due to C5a. Endotoxins have been reported to generate C5a activity (41) and therefore it was not unexpected to find that Hib LPS could generate C5a activity. Of interest was that C5a activity in serum incubated with Hib LPS was as great as that of serum incubated with $S$. typhimurium LPS. We found PMN shape change to be a very sensitive assay for C5a activity. Since nanogram quantities of either LPS incubated in serum could induce PMN shape change, only small amounts of C5a may need to be generated to demonstrate activity in this assay.

Generation of $\mathrm{C} 5 \mathrm{a}$ by bacterial components would normally operate as a defense mechanism against the bacteria by attracting PMNs to the site of infection. Bacterial components that interfere with clearance or killing of bacteria by PMNs, however, may be important virulence factors. The effect of Enterobacteriaceae 
I.PS on PMN function has been well studied and recently reviewed (41). We examined the direct effect of Hib L.PS on PMN function, as determined by measurement of chemiluminescence and phagocytosis. Hib I.PS, but not S. Irphimurium I.PS, could directly stimulate chemiluminescence by human PM.Vs. In addition. Hib L.PS significantly decreased the capability of PMNS to ingest opsonized Hib. Salmonella Rb L.PS and Hib lipid $A$ also diminished PMN phagocytosis, whereas the capsular polysaceharide and the lipid-free oligosaccharide of Hib I.PS had no effect. Therefore, the lipid $A$ of Hib would appear to be the component responsible for the detrimental effect of I.PS on PMV phagocytosis. S. typhimurium I.PS, in contrast. had a slight stimulatory effect on PMN phagocytosis. These results are consistent with those reported by Hendricks and coworkers (34, 45). who compared theffect of Escherichia coli J5 I.PS to that of the smooth parent. E. coli (0111:B4. E. coli J5 I.PS, but not 0111:B4 IPS diminished PMN phagocytosis and chemotaxis. and directly stimulated PMNs in chemiluminescence studies. The lipid $A$ was determined to be the active moiety and the detrimental effect of the 1.PS could be prevented by scavengers of oxygen radicals. The authors presented evidence that generation of $0 x y$ gen radicals, through stimulation of the PMNs by lipid $A$. was toxic for the phagocytic cells and inhibited their antibacterial functions. The large amount of carbohydrate present on $E$. coll ()111:B4 I.PS appeared to block the activity of the lipid $A$ on PMNs, but the core oligosaccharide of $l:$ coli J5 L.PS did not. Enterobacteriaceac lipid $A$ has been shown to bind to receptor sites on PMNs and thereby influence PMN function (40)). It is conceivable that a large polysaccharide. but not an oligosaccharide, can block the binding of lipid $\wedge$ to the receptor sites on PMNs. The antigenic (46) and biologic (2) similarity of Hib lipid $A$ to enteric lipid $A$ would suggest the same mechanism of action is responsible for affecting PMN function by Hib lipid $\wedge$. and that the oligosaccharide does not block this activity.

Hib I.PS has been shown not be microheterogenous in respect to molecular weight (47). This variation in molecular weight (and probably structure) may play a partial role in influencing the relative virulence of some Hib strains. Zwahlen $"$ al. $(48)$ showed that when a virulent strain of Hib was transformed with a 10) kilobase-pair fragment of I Iib DNA. the transformant developed a lower molecular weight I.PS, an alteration in one outer membrane protein, and became serum-sensitive in vitro and avirulent in rats: there was no change in capsular polysaccharide content. Kimura and Hansen (49) isolated two strains of Hib that failed to react with 1 wo monoclonal antibodies reactive with all other strains tested and were less virulent than other Hib strains for infant rats. Isogenic variants were isolated that reacted with the monoctonal antibodies and that were virulent in rats. There was no change in the content of capsular polysaccharide or in the outer membrane protein profile, but the I.PS of each variant was of higher molecular weight than the LPS of the parent strains. These results indicated an alteration in the structure or molecular weight of the I.PS appeared to play some role in increasing the virulence of Hib. Furthermore. Grossman and I.evie (6) and liang-Takasaki 't al. (7, 8) have shown that for Salmonella I.PS the structure of the () side chains is more important than length in regard to complement activation and generation of opsonic ( 3 b. In regard to Hib. different strains with structural differences in their I.PS may interact with complement and affect PMN functions differently, which in turn may influence the virulence of individual strains.

Acknowledgments. The authors thank Dr. Robert Baughn (Veterans Administration Medical (enter. Houston. IX) for densitometric scanning of complement proteins and Dr. (iregory Buffone (Department of Clinical Chemistry. Texas (hildren's Hospital, Houston. TX) for advice and technical guidance on electrophoresis and immunofixation of complement and for review of the manuscript.

\section{RIFHERENCIS}

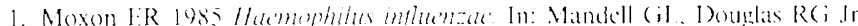
Bennet Jl: (eds) Principles and Practice of lnfectiones D )iseases. Znd ed. John Wiley \& Sons Now York. pr 1274-1278

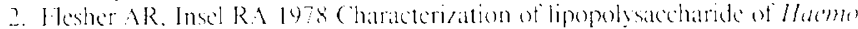

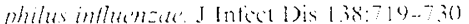

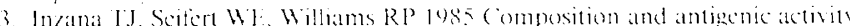

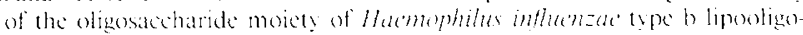
saccharide. Infect $1 \mathrm{~mm}$ mon $48: 324 \ldots 30$

4. Hitcheock PJ. I cive I. Makela 1H. Reitschet F: I. Stritmatter W. Morrisen Ix 1986 lipepolysaceharide nomenclature--past, present, and future. I Bacteriol 160.6099 .705

5. Morrison I) . Kline 1.51977 Activation of the chassical and properdin pathways of complement by bacterial lipopolysacchatrides (1.PS). I Immunol $118: 362-368$

6. Cirossman ․ I.cive l 1984 Complement activation via the alternative pathwal by puriticed Salmomella lipopols saccharide is affected by its structure but not its ()-antigen longh 1 lmmunol $132 \cdot 376-385$

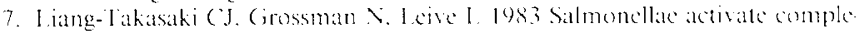
ment differentially via the alternative pathway depending on the structure of their lipepolysactharide (0-antigen. J Immunol 130:1867-1870)

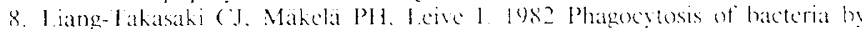
macrophages: changing the earbohdedrate of lipopolysaccharide alters intermacron with complement and macrophages 1 Immunot $128: 1229$. 123

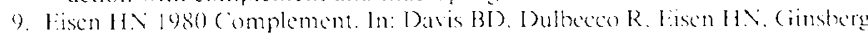
HS (eds) Mierobiology, ird ed. Harper and Row. Hagerstown. MI), pp 451466

11). Allen RJ. Scon (ik 1980 The eflect of puriticd lipopolysachatrick on the bactericidal reaction of human serum complement. I (ien Microbiol 1 17:65.5 72

11. Taylor PW. Rohinson MK 1980 Determinants that increase serum resistance

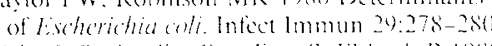

12. Weiss J. Beckerdite-(Quagliata S. FEbach P 19so Resistance of gram-negatise bacteria to purified bactericidal leukocste proteins. Relation to binding and

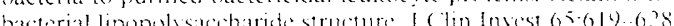

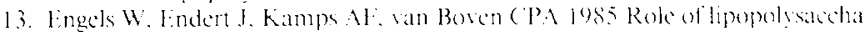

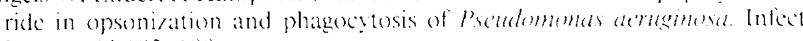
Immun $+9: 182 \cdots 189$

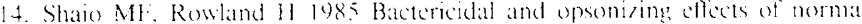

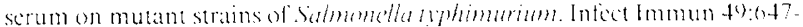
653

15. Anderson P. Johnson RB Ir. Smith DH 1972 Human scrum activitics agamst

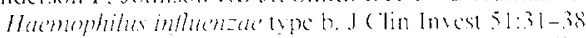

16. Branefors P. Dahlberg I 1980) Sorum backericidal offect on capsulated and

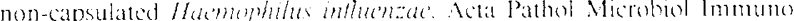
Scand (6) $88: 47-50$

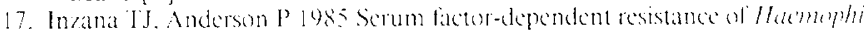

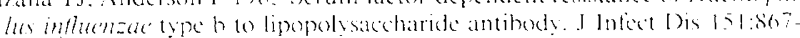
877

18. Inzana TJ 1986 A chemically detined medium induess resistance oo lipopoly

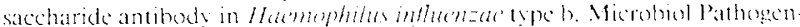
sis $1.483-489$

19. Crosson FJ Jr. Winkelstein JA. Moxon IER 1976 Participation of complement

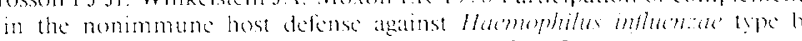
septicomia and meningitis. Infect Immun 14:882-887

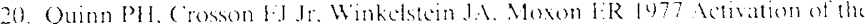

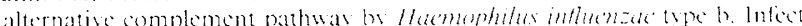
Immun 16:4(0)-402

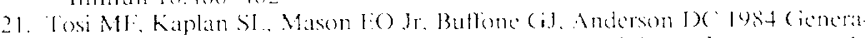

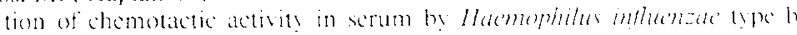
Infect Immun $43.593 .5(9) 9$

22 Veuman SI Waldo B Johnston RB Jr 1973 Scparation of serum bictericidal

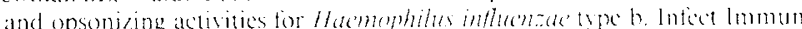
$8: 488-490$

23. Weller PF Smith AI. Smith DH. Anderson P 1978 Role of immunity in the

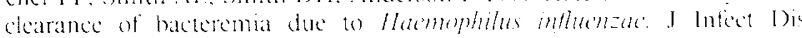
$138: 427-4.36$

24. Loeb MR. Zachary Al Smity D)H log I lsolation and partal (hatactem/atton

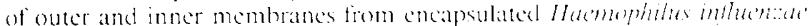
type b. J Bacteriol 1+5.596-6(t)-4

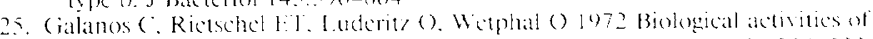
lipid A complexed with bovine-serum albumin. Eur I Biochem $31: 2,30$ - 2:3

26. (Galanos (. I uderity () 1976 The role of the phesical state of lipopols saceharides in the interaction with complement. Fur I Biochem (05:40).3-408

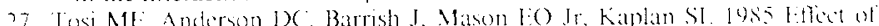

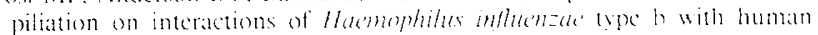
polymorphonuclear keukocytes. Infect Immun 47.780 - 785

28. Riches DWH. Stanworth DR 1980 A simple new method of meastring the capacits to altivate the alternative complement pathwas. Immund lett $1.363-306$

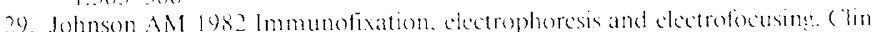
(hem $28: 1797-1800$

30. Smith (W. Hollers KC Patrich RA. Hasset ( 1979 Motility and adhesiseness

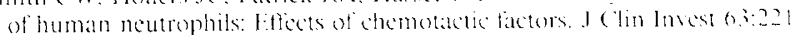
20 
31. Craddock PR, Hammerschmidt DE, Moldow CF, Yamada O, Jacob HS 1979 Granulocyte aggregation as a manifestation of membrane interactions with complement: possible role in leukocyte margination. microvascular occlusion and endothelial damage. Semin Hematol 16:140-147

32. Craddock PR, Hammerschmidt D. White JG, Dalmasso AP, Jacob HS 1977 Complement (C5a)-induced granulocyte aggregation in vitro: a possible mechanism of complement-mediated leukostasis and leukopenia. J Clin Invest 60:260-264

33. Kaplan SL, Umstead CL, Mason EO, Anderson DC, Parke JC Jr, Feigin RD 1981 Assessment of Haemophilus influenzae type b opsonins by neutrophil chemiluminescence. J Clin Microbiol 13:352-539

34. Hendricks PAJ, van der Tol MF, Thyssen RMWM, van Asbeck BW, Verhoef J 1983 Escherichia coli lipopolysaccharides diminish and enhance cell functions of human poiymorphonuclear leukocytes. Infect Immun 41:294-301

35. Kaplan SL, Mason EO, Jr, Johnson G, Broughton RA, Hurley D, Parke JC Jr 1983 Enzyme-linked immunosorbent assay for detection of capsular antibodies against Haemophilus influenzae type b: comparison with radioimmunoassay. J Clin Microbiol 18:1201-1204

36. Brown BW Jr 1971 Statistics: A Biomedical Introduction. J. Wiley \& Sons, New York

37. Steele NP, Munson RS Jr, Granoff DM, Cummins JE, Levine RP 1984 Antibody-mediated alternative pathway killing of Ilaemophilus influenzae type b. Infect Immun 44:452-458

38. Tarr PI, Hosea SW. Brown EJ, Schneerson R, Sutton A. Frank MM 1982 The requirement of specific anticapsular IgG for killing of Haemophilus influen$z a e$ by the alternative pathway of complement activation. $\mathrm{J}$ Immunol 128:1772-1775

39. Galanos C, Rietschel ET, Lüderitz O, Westphal O 1971 Interaction of lipopolysaccharides and lipid A with complement. Eur J Biochem 19:143-152
40. Proctor RA 1979 Endotoxin in vitro interactions with human neutrophils: depression of chemiluminescence, oxygen consumption, superoxide production, and killing. Infect Immun 25:912-921

41. Wilson ME 1985 Effects of bacterial endotoxins on neutrophil function. Rev Infect Dis 7:404-418

42. Buffone GJ 1986 Principles of immunochemical techniques. In: Tietz NW (ed) Textbook of Clinical Chemistry. WB Saunders Co, Philadelphia, pp 209 235

43. Liang-Takasaki CJ, Saxén H, Mäkelä PH, Leive L 1983 Complement activation by polysaccharide of lipopolysaccharide: an important virulence determinant of salmonellae. Infect Immun 41:563-569

44. Cooper NR, Morrison DC 1978 Binding and activation of the first component of human complement by the lipid A region of lipopolysaccharide. $\mathrm{J} \mathrm{Im}$ munol 120:1862-1867

45. Hendricks PAJ, Verhoef $\mathbf{J} 1983$ Effect of lipopolysaccharide, lipid A and polysaccharide on phagocytic cell function. Agents Actions 13:498-499

46. Johns MA, Bruins SC, McCabe WR 1977 Immunization with R mutants of Salmonella minnesota II. Serologic response to lipid A and the lipopolysaccharide of Re mutants. Infect Immun 17:9-15

47. Inzana TJ 1983 Electrophoretic heterogeneity and inter-strain variation in the lipopolysaccharide of Haemophilus influenzae. J Infect Dis 148:492-499

48. Zwahlen A, Rubin LG, Connelly CJ, Inzana TJ, Moxon ER 1985 Alteration of the cell wall of Haemophilus influenzae type b by transformation with cloned DNA is associated with attenuated virulence. J Infect Dis $152: 485$ 492

49. Kimura A, Hansen EJ 1986 Antigenic and phenotypic variations of Haemophilus influenzac type b lipopolysaccharide and their relationship to virulencc. Infect Immun 51:69-79 